\title{
REVIEW I Collective Participation and Audience Engagement in Rap Music
}

\author{
David Diallo
}

Cham: Palgrave Macmillan, 2019

\section{Sergio Pisfil}

\author{
Universidad Peruana de Ciencias Aplicadas \\ sergio.pisfilz@gmail.com
}

This engaging book appears in the context of a growing interest in hip hop research, tangible in the recent creation of peer reviewed journals such as Global Hip Hop Studies (2019) and the Journal of Hip Hop Studies (2014), the launch of a "Hip Hop Studies Series" by the University of California Press (2018) and regular international gatherings like Show \& Prove, a biennial Hip Hop Studies Conference (since 2010) and the annual meetings of The European HipHop Studies Network (since 2018). This monograph also arrives in a meaningful time in which live music has started to attract scholarly research. This includes Simon Frith et al.'s two volumes (and a third in its way) on the history of live music in Britain (2013; 2019), Chris Anderton's research on festivals (2019), Robert Edgar et al.'s book on arena concerts (2015) and Angela Cresswell-Jones and Rebecca Jane Bennett's edited collection on live music in the digital era (2015), to name a few.

The aim of the author, very clear from the outset and constantly reminded throughout this book, is to provide evidence to understand rap as a live-oriented form of music. Drawing from previous research (much of which relies on oral history) and the analysis of paradigmatic recordings, Diallo examines the way rap music constantly uses an interlocutor (physical or virtual) as a strategy to generate collective participation. To do so, he carefully and cleverly examines how lyrics through call and response, intertextuality, and other rhetorical strategies such as addressing the audience in present tense - stimulate audience engagement. Overall, the argument of the book is that collective participation is to be found throughout the various changes in rap's history, from live music to recorded, from party lyrics to social lyrics, and from solo performances to competitive or "battle" shows. His division of rap's history into periods 1974-1978 (formative period), 1979-1992 (craftmanship period) and 1993-2010 (celebrity period), gives a structured way to present chapters and, most of all, provides a helpful tool for the non-specialist to follow his historical arguments quite easily, making this an accessible reading for

IASPM Journal vol.10 no.2 (2020) 
anyone interested in rap as an art form. It is unclear why post-2010 rap has not been considered in his periodization, but the attention to earlier periods allows the author to offer historical grounds to his arguments and locate the live origin of rap in its formative years in the Bronx.

Although his focus is on the lyrical elements of the music, Diallo does examine other aspects that help enhance collective participation in rap. His study of gestural elements and non-verbal communication on stage (Chapter 7) is particularly enlightening. Likewise, his analysis of recorded music (Chapter 5) provides an interesting parallel to live music: instead of studying these two media as producing conflicting aesthetics, the author shows how live dynamics are maintained on rap recordings through various mechanisms such as studio production and lyrical content. However, although this chapter brings important insights into the connections between live and recorded contexts, the theoretical grounds on which he poses this continuum is less acute. The opposition live/recorded music in terms of technological mediation or, more generally, to oppose the stage to mediated performance ( $p$ 81) overlooks the different ways in which live music is also a highly mediated practice. At least since the late 1960s and without a doubt in the periods with which Diallo's book is concerned, live music has involved technologicallymediated presentations. Portraying live music processes without this fundamental component reinforces ideas of "immediacy" that obscures different creative practices of performances onstage. Perhaps a different conceptual consideration of liveness as a tool to analyse music would have allowed Diallo to reflect on audience engagement beyond the performer, and include other elements like the stages themselves, or the sound systems (and their ability to produce powerful bass lines, for example), in the mediation of live music.

With this exception, Diallo presents a rather critical study that continuously and sharply inspects theoretical issues. This is not only evident in his revisiting of the concept of call and response (Chapter 2) but also in his inclusion of the social settings that have influenced rap's creative process, including gang culture (pp 9395) and racial dynamics. His commitment to analyse social relevance in audience engagement is particularly visible in Chapter 8 where he addresses the use of $n$ words by non-Black members of the audience when singing along. Without arriving at firm conclusions, this chapter presents an interesting portrayal of concerts as sites that are regulated by their own conventions and where previously censored behaviours, like the use of these terms by non-Black fans, may be acceptable. It also shows the complexities of studying the ecology of live music where social (and artistic) conventions are not only shaped by musicians' decisions but also by other elements such as the size of venues and audience demographics.

Diallo's book will appeal to anyone interested in studying rap as a creative process and in learning about stimulating ways to understand the relationship between live and recorded media, a gap still to be fulfilled in live music studies. With its emphasis on the fundamental role that collective participation plays in rap music, Diallo's monograph provides a useful approach to examine and experience one of the most popular music genres today.

\section{References}

Anderton, C. 2019. Music Festivals in the UK: Beyond the Carnivalesque. Abingdon \& New York: Routledge.

Cresswell-Jones, A. and Bennett R. J. Eds. 2015. The Digital Evolution of Live

Music. Oxford: Chandos Publishing. 
Edgar, R. et al. Eds. 2015. The Arena Concert: Music, Media and Mass Entertainment. New York: Bloomsbury.

Frith, S. et al. 2013. The History of Live Music in Britain, Volume 1: 1950-1967: From Dance Hall to the 100 Club. Farnham \& Burlington: Ashgate.

Frith, S. et al. 2019. The History of Live Music in Britain, Volume 2: 1968-1984: From Hyde Park to the Hacienda. Abingdon \& New York: Routledge. 